\title{
Kliment Yefromoviç Voroşilov'un Türkiye'yi Ziyareti ve Türkiye-Sovyet Rusya İlişkilerine Katkısı
}

\author{
Yrd.Doç.Dr. Erdal AYDOĞAN*
}

\section{ÖZET}

“Mustafa Kemal Paşa liderliğindeki Milli Mücadelenin başarılt olmasında Türk milletinin fedakarlıkları, savaş kabiliyeti kadar dış dünyadan gelen yardımların da katkısı büyük olmuştur. Bu yardımların alındığı ülkelerin başında da Sovyet Rusya gelmekteydi. Böylece iki ülke arasindaki tarihsel komşuluk ve dostluk bu süreçle daha da kuvvetlenmiş oldu. Bu dostluk bağları 1923-1933 yılları arasında iki ülkenin devlet adamlarının karşılıkl ziyaretleriyle kuvvetlendirilmeye çalışılmıştır. Voroşilov'un Türkiye'yi ziyareti de iki dünya savaşı arasında bu dostluğa vurulmuş bir perçindir."

Anahtar Kelimeler: Sovyet Rusya, Vyaçeslov Mihayloviç Molotov, İzmir Vapuru, Ankara Palas Oteli, Tevfik Rüştü.

\section{Turkey Visit of Kliment Yefromoviç Voroşilov and Contribution To The Affairs of Turkey-Soviet Russia \\ SUMMARY}

The helps coming from outer world as well as combat ability and courages of Turkish Nations have contributed in the success of National Struggle under the leader of Mustafa Kemal Pasha. Soviet Russia was on the spear of these contributors. So, Historic Friendship and neighborhood between two countries became for stronger. These frienship bonds were made stronger by mutual visits made by two countries statesmen. The visit of Voroşilov is a strong nail hammered for this friendship between two World Wars.

Key Words: Soviet Russia, Kliment Yefromoviç Voroşilov, Molotov, Smyrna steamship vessel, Ankara Palace Hotel.

\footnotetext{
• Atatürk Üniversitesi, Atatürk Illkeleri ve İnkılâp Tarihi Enstitüsü Öğretim Üyesi.
} 


\section{GİRIŞ}

Yakın dönem Türk-Rus ilişkilerinin takip ettiği seyir fevkalade dikkat çekici olmuştu. Birinci Dünya Savaşı'nda istediklerine ulaşamayan Çarlık Rusyası yerini Bolşeviklerin ilan ettikleri "Proleterya iktidarına bırakmış ve devrimin lideri Lenin, "kimsenin bir karış toprağında gözümüz yoktur. Fakat kimseye de toprağımızdan bir karış yer veremeyiz" demek suretiyle yeni devletin politikasını özetlemiş, maksatlarının ise "Rus milletinin yaşayış tarzını 1slah edecek bir derecede yükseltmek ve topraklarının istiklalini temin etmek" olduğunu ifade etmişti. ${ }^{1}$

Sovyet Rusya'nın ve komünizmin geleceği açısından çok önemli olan, E.H.Carr'ın da altını çizdiği, "kendi kaderini tayin hakkı" öğretisiyle, "Büyük Rus Şovenizmi” gibi suçlamalardan da bu politikalar sayesinde bir anlamda kurtulmuş olacaktı. ${ }^{2}$

Bu süreçte Sovyet Rusya'nın sosyo-politik, ekonomik vs alanlarda başarılı olması dünya proleteryasının da başarısı olacağı anlamına gelmekteydi. Amaçlarının gerçekleşmesi için de daha ilk günlerden itibaren, şiddetli propaganda yapma yolu seçilmişti. Ayrıca büyük bir orduya sahip olması hasebiyle hiç durmadan kadrolarını genişleterek silahlanma yarışına dahil oldular. Güçlü ordu onların en büyük güvencesini oluşturmaktaydı ${ }^{3}$.

Dönemin politik atmosferinde Sovyet Rusya'nın önemsediği bir diğer konu da yeni kurulmuş olan Büyük Millet Meclisi Hükümetiyle dostane ilişkiler kurmak istemesiydi. Bu dostluk her iki tarafın menfaatlerine uygun düşmekteydi. Ankara; bu dostluk sayesinde içinde bulunduğu yalnızlık fobisinden kurtulabilmeyi, Doğu'da sınır güvenliğini tesis ederek Batı'da ülkenin işgaline soyunan başta İngiltere olmak üzere yandaşlarına karşı daha bir özgüvenle mücadele edebilmeyi hedeflemişti. Moskova cephesi ise ortak düşmanlara karşı Anadolu'nun yanında olması ve milli mücadeleye silah, para ve lojistik vs olarak destek çıkması, karşılığında da yeni devletinin rejiminin Komünizm olacağı ümidini taşıyordu ${ }^{4}$. Bu bağlamda Komünistler, Anadolu ile ilgilenmeye ve bir takım aracılarla temas kurmayı dahi denemişlerdi ${ }^{5}$. Bu kişiler arasında en dikkat çekeni ise Voroşilov Heyeti ile

${ }^{1}$ Leon Cahen, Raymond Ronze, Emile Folinais, 1919'dan 1937 Yılına Kadar Dünya Tarihi, (Çvr.Galip Kemalî Söylemezoğlu), İstanbul, 1939, s.462.

${ }^{2}$ E.H.Carr, Sovyet Rusya Tarihi Bolşevik Devrimi (1917-1923), (Çvr. Orhan Suda), c.I, 2.bs., İstanbul, 2002, s.249

${ }^{3}$ Edmond Rossier, Avrupa'nın Siyasi Tarihi (1815-1919), (Çvr.Ali Kemal Aksüt), İstanbul, 1943, s.293.

${ }^{4}$ Rıfkı Salim Burçak, Moskova Görüşmeleri ve Dış Politikamız Üzerindeki Tesirleri (26 Eylül 1939-16 Ekim 1939), Ankara, 1983, s.9.

s "Bu sırada İstanbul'da bulunan bazı Bolșevik Ruslar da bizimle temas kurdular. Balıkesir'e gelen salâhiyetli bir Rus'un yanında, tercümanlık yapmak ve bir taraftan da bize faideli olmak maksadıyla bu işe girdiği anlaşılan Emrullah Bey adında (sonradan maarif müfettişliklerinde bulunmuştur) bir tercüman vardı. Emrullah Bey'in tercüme etmekte olduğu, Bolşevik Rus'un bize yaptığı teklifte:

Mücadelenizi Rus dostluğuna dayanarak devam ettireceğinizi, kapitalist alemine karşı Ruslar ile aynı fikirde olduğunuzu ilân edersek, bize istediğimiz kadar silâh, cephane, para ve hatta icab ederse Türkistanlı asker yardım yapacaklarını" söyledi. Biz bunları kabul etmedik, 
Türkiye'yi ziyaret edecek olan Albay Budenny idi. Mustafa Kemal kendisiyle Havza'da görüşmüştü. Budenny, Mustafa Kemal Paşa'ya "Bolşevik Rusya'nın silah ve cephane ile para yardımını vadediyor, buna mukabil müşterek düşmanları olan İtilaf Devletlerine karşı, Türkleri mücadeleye davet ediyordu., ${ }^{\prime 6}$

Sovyetlerle bu temasların gerçekleşmiş olması kuvvetle muhtemeldi. Çünkü bu temas; Komünizm rejimi adına büyük önem taşımaktaydı. Merkez-Çevre ilişkisi komünizmin geleceğini belirleyecekti. Dolayısıyla Sovyet Rusya, Anadolu'da olanlara duyarsız kalamazdı. Bunun için Anadolu'nun ortak düşmanlara karşı mücadelesini şiddetle destekliyordu.

Buna rağmen Sovyet liderlerin beklentileri gerçekleşmeyebilirdi. Çünkü Anadolu harekâtının lideri bu temasları askerî ve siyasî olarak kabul ediyordu ve zaman zaman verdiği mesajlarda da "Sınıf Mücadelesi" vermediklerinin altını çiziyordu. Buna rağmen Türk komünistlerin ülkede teşkilatlanmalarına da Sovyetlerle iyi geçinmek adına göz yumulduğu dikkatlerden kaçmıyordu. Türk Komünistler ülkede, Moskova grubu ve Paris grubu olarak toplanıyordu. Moskova grubu Mustafa Suphi etrafında Paris grubu ise Vedat Nedim Tör ve Ethem Nejat gibi Almanya'da eğitim görmüş, Alman Komünist Partisi'nin ilk eylemi olan Spartaküs ayaklanması sırasında Avrupa'daki Bolşevik hareketlerden ilham almış kişilerden oluşmaktaydı. Ancak bütün dünyada olduğu gibi Türkiye'de de komünizme karşı bir endişe ortaya çıkmıştı. ${ }^{7}$ Hatta Mustafa Kemal Paşa, Kurtuluş

ancak bize sorulduğunda Ruslara karşı bir düşmanlığımız olmadığını ve kendilerini dost bir komşu olarak tanıdığımızı ifade edeceğimizi belirttik. Ayrılır iken bize gizli olarak silah ve cephane göndermeye çalışacağını vaat etti. Sonradan bu Rus'un İstanbul'a dönüşünde, İngilizler tarafından tevkif edilerek belirsiz bir yere gönderildiğini ve Emrullah Bey'in de bu issten dolayı İngilizler tarafından șiddetle takip edildiğini öğrendim." Kâzım Özalp, Milli Mücadele (1919-1922), Ankara, 1971 s.74. Yine bir başka görüşme, Yerasimos'a göre Havza'da Mustafa Kemal Paşa ile Rus Albay S.M.Budiyenni başkanlığında bir Sovyet heyetiyle görüssmesidir. Buna göre; "Anadolu'ya gelenler orada Mustafa Kemal'in girişimlerini öğrenirler ve onunla Haziran'ın ilk günlerinde Havza'da görüşürler. Konuşma herhalde Anadolu hareketinin özellikleri ve yardım olasılıkları konuları çevresinde döner. Mustafa Kemal bu temsilciler ve Odessa'daki grup aracılığıyla Moskova Sovyeti ile iliskiler kurmak ister." Stefanos Yerasimos, Türk-Sovyet İlişkileri, (Ekim Devriminden Milli Mücadeleye), İstanbul, 1979, s.108-109.

${ }^{6}$ Hüsameddin Ertürk'ün anlattıklarına göre Mustafa Kemal ile Budenny arasında şu ilginç konuşma geçmiştir:

- Acaba General Hazretleri, Anadolu'da kurulacak hükümet için nasıl bir rejim düșünüyorlar?

Mustafa Kemal, muhatabının maksadını pek güzel anlamış ve hemen şaşırmadan cevabını vermişti:

- Tabii Sovyetlerin, Şûralar Cumhuriyetine benzer bir hükümet tarzı!..

- Yani Bolşevikliğin prensipleri üzerine kurulmuş bir cumhuriyet değil mi Genearelim!..

- Öyle olacak, devlet sosyalizmi dersek, daha doğru söylemiş oluruz.

-Yalnız, sosyalizm, içtimai sahada hüküm süren bir tarzdır, biz sizin komünizmi de gözden geçirmenizi istiyoruz.

Ancak büyük komsunuz Rusya, o zaman size elinden gelen yardımı yapacaktır."

Hüsameddin Ertürk, İki Devrin Perde Arkası (Yazan Samih Nafiz Tansu), İstanbul, 1964, s.339

${ }^{7}$ Aydın Yalçın, Türk Komünizmi Üzerine Bazı Gözlemler, Ankara, 1977, s.18-19. 
Savaşı'nın sonlarına doğru bütün ülkede komünistlere ve komünizme karş1 sert tepkiler göstermiş, bir çok kişiyi tutuklattırmıştı.

Bütün bunlara rağmen Sovyet Rusya, bu temas ve politikalarının sonucunda komünist rejimi Anadolu'ya ihraç edememiş ve bu politikasında başarısız olmuştu. Ancak "kendi ülkesinin güvenlik şartları bakımından beklediği neticeyi almıştı. Zira, Sovyet Rusya'nın geleceği, huzur ve güveni biraz da Türk'ün zaferine bağlıydı. Bu mücadelede Türkiye'nin yenilgisi Anadolu'yu İngiltere'nin nüfuzu altına düşürecek, İngiltere büyük Yunanistan ve büyük Ermenistan yolu ile Yakın Doğu'ya hakim bir duruma geçecekti. Bu ise daimi bir tehlikeyi Sovyetlerin kapısına kadar yaklaştırmak olacakt ${ }^{8}$.

\section{A-Kurtuluş Savaşı Yıllarında Türk-Sovyet İlişsileri (1920-1923)}

Yakın Dönemde Türk-Sovyet İlişkilerini belirleyen en önemli süreç 1917 yılında Rusya'da ortaya çıkan Ekim Devrimi'ydi. Bu süreç sadece Rusya'yı etkilemedi, aynı zamanda Osmanlı Devletini de uluslar arası arenada yalnızlaştırdı ve Birinci Dünya Savaşı sonrası da Osmanlı ülkesi emperyalist eylemlerin ortasında kaldı.

$\mathrm{Bu}$ süreç Mustafa Kemal Paşa liderliğinde Kurtuluş Savaşının başlaması ve yeni bir devletin kurulmasıyla başka bir mecraya kavuştu. Ancak bu sürecin başarıya ulaşması parasal ve lojistik imkanlar ölçüsünde olacağından genç devlet stratejik bir ortak bulmalıydı. İşte o günün şartlarında aranan ortak bulunmuştu; bu devlet Bolşevik Rusya idi. "Milli hükümetinin muhtaç olduğu dış kaynağı Batı'da bulmanın imkanı yoktur" gerçeği BMM Hükümeti'ni Rusya ile ilişkiler kurmaya zorladı. ${ }^{9}$ Mustafa Kemal Paşa gelinen aşamayı şu görüşleriyle ifade eder: "Bizim Ruslarla olan münasebatımızda esas olarak kapitalizm aleyhine yani komünizm esasatına temas dahi edilmemiştir. Görüşebilmek için komünist olunuz, veyahut olmağa mecbursunuz diye kimse bize bir şey demediği gibi sizinle dost olabilmek için komünist olmağa karar verdik dememişizdir. Böyle bir esas mevcut değildir""10.

$\mathrm{Bu}$ dostluk arayışları Bolşevik Rusya açısından büyük önem taşımaktaydı. I. Dünya Savaşı'nda müttefiği olan ve kader birliği yaptığı İngiltere'nin yeni politikalarıyla karşı karşıya kalmış, Ruslar güneyden sıkıştırılmıştı. Ayrıca Boğazların kontrol altına alınması Rusya'nın tarihsel politikalarına ters düşüyordu. Bolşevik Devrimden sonra kurulan geçici Rus Hükümeti'nin bundan böyle "ilhaksız" bir barış yapacağı beyanları eski dostların Rusya'ya karşı politikalarını gözden geçirmelerini etkilemişti. İngilizlerin politikalarına karşılık Rusya'da yeni politikasını, gelişmiş ülkelerin işçi kitlelerini ve sömürgeleştirilmiş Müslüman halkların elde

\footnotetext{
${ }^{8}$ Burçak, Moskova Görüşmeleri, s.10-12.

${ }^{9}$ Faruk Sönmezoğlu, "Kurtuluş Savaşı Dönemi Diplomasisi”, Türk Dış Politikasının Analizi, (Der) Faruk Sönmezoğlu, İstanbul, 2001, s.58.

${ }^{10}$ Enver Ziya Karal, Atatürk'ten Düşünceler, Ankara, 1956, s.125.
} 
edilmesiyle Doğu halklarını özellikle Hindistan ve Afganistan'ı İngiltere'ye karşı örgütlemek ve ayaklandırmak olarak belirlemişti ${ }^{11}$.

Bu gibi gelişmeler Ankara-Moskova yakınlaşmasına ortam hazırladı. $\mathrm{Bu}$ yakınlaşma İngiltere ve diğer Avrupa devletleri tarafından endişeyle karşılanmaktaydı. Hatta Mayıs ayında Sovyet-İngiliz antlaşmasının görüşmeleri Londra'da devam ederken Başbakan Lloyd George, antlaşmaya Sovyetlerin Ankara'ya yardım etmemesi şartını koydurmak istemiș ama başarılı olamamıștı. Sovyetlerin Ankara'ya karşı işlediği politika resmi ve gayri resmi düzeylerde farklılıklar göstermiș olmasına rağmen Ankara'ya karşı ideolojik beklentileri hep gizli tutulmuştu ${ }^{12}$. Ancak Sovyetlerin Anadolu harekatına komünist bir kimlik kazandırmak istediği anlaşılmakta bunun için de bazı komünist grupları desteklemeyi uygun görmekteydi ${ }^{13}$. Ayrıca Komünist ideologların Batı'da komünist bir devrimin gerçekleşmeyeceğini görmesi sonucu, Komünizmin geleceğini Doğu'da görmüşler ve çalışmalarını buralara kaydırmışlardı. Yeni Rus politikasının siklet merkezi olarak da Anadolu'yu görmüşlerdi. Bu yüzden de Türk Milliyetçiliğini ve mücadelesini desteklemeliydi. ${ }^{14}$

Mustafa Kemal Paşa, gelinen aşamayı, Sovyetlerin samimiyetini pratikte görmek istemiști. Bu maksatla Sivas Kongresi'nin toplandığ 1 Eylül 1919'da Sivas'a gelen Halil Kut Paşa'yı Moskova'ya göndermiş, yapılacak yardımları ve teması sağlamak istemişti. ${ }^{15}$ Ayrıca kısa bir süre sonra da Moskova ile temasın gayri resmi yollardan değil de bir kanaldan yapılması için Hariciye Vekili Bekir Sami Bey başkanlığında bir heyeti de Moskova'ya gönderdi ${ }^{16}$.

${ }^{1}$ Reşat Sagay, XIX Yüzyıllarda Büyük devletlerin Yayılma Siyasetleri ve Milletlererası Önemli Meseleler, İstanul, 1972, s.210-211; Sönmezoğlu, "Kurtuluş Savaşı...", s.58.

“'TBMM'nin açılmasından üc gün sonra, 26 Nisan 1920'de Mustafa Kemal, Lenin'e gönderdiği bir mektupla Ankara ve Moskova arasında normal münasebetlerin kurulmasını "askeri ve siyasi bir ittifak ile" yabancı emperyalizmine karș1" birlikte mücadele edilmesini istemis..." Fahir Armaoğlu, 20.Yüzyıl Siyasi Tarihi (1914-1980), Ankara, 1983, s.310. Bu mektubun varlığı tartışma konusudur. BMM Hükümeti Reisi olarak Lenin'e Yeni Türkiye’yi kurarken, şu esasları kabul ettiğini bildirmiş, 1-Türkiye'nin istiklalinin tanınması, 2-Türklerle meskun yerlerin Türkiye'de kalması, 3-Suriye ve Arabistan'ın istiklallerinin tanınması, 4Türk Ermenistan'ına, Kürdistan'a, Lazistan'a, Batum çevresine Doğu Trakya'ya ve TürkArap halkının yaşadığı sahada, ahalinin kendi mukadderatını kendilerinin tayin etmeleri BMM'nce karar verilmis olması, 5 ve 6 . maddeler azınlık ve Boğazlara aitti" görüleceği üzere bu maddeler Misak-1 Milli'yi tadil etmek anlamına gelir ki, bu şekliyle imkansızdır. Akdes Nimet Kurat'da bunun Sovyet yazarları ve tarihçileri tarafından propaganda maksatlı olduğunu belirtir. Akdes Nimet Kurat, "Kurtulus Savaşı'nın Balarında Mustafa Kemal Tarafından Lenin'e Yazıldığı iddia Edilen bir Mektubun Mevcut Olmadığı Anlaşıldı” Türk Kültürü, 97/IX (Kasım 1970), s.26 vd.

${ }^{13}$ Sönmezoğlu, "Kurtuluş Savaşı...", s.60.

${ }^{14}$ Baymirza Hayit, "Bazı Sovyet Kaynaklarının Atatürk Hakkındaki Düşünceleri”, Töre, 131(Nisan 1982), s. 42.

is "1920 yılında deniz yolu ile Trabzon'a bir miktar silah ve cephane gönderdi, ayrıca 100.000 lira değerinde bulunan külçe altını da Karaköse'de 11. Tümen'e teslim etti" Selahattin Tansel, Atatürk ve Kurtulus Savașı (1919-1922), Ankara, 1965, s.73.

16 Mustafa Öztürk, Atatürk döneminde Türkiye'nin Kafkasya Politikası (Yayınlanmamış Yüksek Lisans Tezi), Ankara, 2005, s.100; Sönmezoğlu, "Kurtuluş 
Böylece Ankara Hükümeti resmi olarak Sovyetler ile siyasi münasebetleri başlatmış oldu. Heyetin amacı Sovyetlerle bir dostluk andlaşması yapmakt ${ }^{17}$. Buralarda yapılan görüşmeler sonucunda ortaya çıkan anlaşma metni imza aşamasındayken Kafkasya Sorunu ve Sovyet temsilcilerinin siyasi tereddütleri sonucu imzalanamadı. Bu aşamada Bolşeviklerin Azerbaycan'ı işgal etmeleri, Ermenistan'la da istedikleri gibi anlaşma imzalamaları görüşmeleri çıkmaza sürüklemiş oldu. 27 Ağustos'ta da Çiçerin'in Bekir Sami Bey'den Ermenilere arazi verilmesi gerektiğini ileri sürmesi görüşmelerin askıya alınmasına sebep oldu ${ }^{18}$.

Böylece görüşmelerin beklenmedik şekilde kesilmesi Sovyetlerin yalnızca doktriner değil siyasi ve emperyalist emellerinin devam ettiğini gösteriyordu. Bu gelişmelerden sonra Kâzım Karabekir Paşa, BMM onayıyla ileri harekatına başlamış Sarıkamış ve Kars'ı aldıktan sonra Gümrü'ye girmiş ve Menşevikler 3 Aralık 1920 Gümrü Antlaşması'nı imzalamak zorunda kalmışlardı. Bu arada Bolşevikler Ermenistan'da iktidarı ele geçirmişler ve buraları Sovyetize etmişler, Ermenistan meselesi de kendiliğinden hallolmuş oldu ${ }^{19}$.

\section{B- Türk-Sovyet İlişkileri (1923-1930)}

Türk-Rus ilişkilerinde önemli bir aşama olan Moskova Antlaşması'na paralel olarak üç Kafkas Cumhuriyeti ile de 13 Ekim 1921 yılında Kars'ta bir dostluk antlaşması, 2 Ocak 1922'de de Ukrayna Sovyet Cumhuriyeti ile dostluk ve kardeşlik antlaşmaları imza edildi ${ }^{20}$.

Mudanya Mütarekesi'nin imzalanmasından sonra başlayacak olan kalıcı barış görüşmelerine Sovyet Rusya'nın, daha önce Moskova Antlaşmasını imzaladığı gerekçesiyle ${ }^{21}$ çağrılmaması yönündeki İtilaf devletlerinin tavrı ortaya çıkınca Sovyet yönetimi, Ankara Hükümeti'yle konferansa birlikte katılma arayışına girmişti. Bunun için de Ankara'ya Semen Aralov'u diplomatik temsilci gönderdi. ${ }^{22}$ Diplomatik girişimler sonucunda da Sovyet Rusya'nın sadece "Boğazlar" konusunda konferansa katılması uygun görülmüștü. Özellikle İngiltere, konferans boyunca "Boğazlar"da Rus tehdidine karş1 ortaya koyduğu tezlerinde Sovyet-Türk bloğunda bir çatlak

Savașı...", s.61. Bekir Sami Bey Heyeti'nde; İktisat Vekili Yusuf Kemal (Tengirșek), Dr.Miralay İbrahim Tali (Öngören), Lazistan Mebusu Osman, Erkan-ı Harbiye Kaymakamı Seyfi (General Seyfi Düzgören) Beyler bulunuyordu.

${ }_{17}$ Mehmet Gönlübol, Cem Sar, Olaylarla Türk Dıs Politikası, (1919-1990), Ankara, 1993, s.19. "Kazım Karabekir Paşa bize askeri müşavir olarak Doktor Tali Bey’le Seyfi Bey'i (sonradan Paşa) vermişti" Yusuf Kemal Tengirşek, Vatan Hizmetinde , Ankara, 2001, s.177.

${ }^{18}$ Sagay, XIX ve XX.Yüzyıllarda...”, s.212; Sönmezoğlu, “Kurtuluş Savaşı...”, s.61.

${ }^{19}$ Armaoğlu, 20.Yüzyıl Siyasi..., s.312.

${ }^{20}$ Bu konuda daha geniş bilgi için bakınız, İsmail Soysal, Tarihçeleri ve Açıklamaları ile Birlikte Türkiye'nin Siyasal Andlaşmaları (1920-1945), c.I, Ankara,1989, s.39-vd.

${ }^{21}$ Taner Baytok, İngiliz Kaynaklarından Türk Kurtuluş Savașı, Ankara, 1970, s.163.

${ }^{22}$ Salahi R. Sonyel, Gizli Belgelerle Lozan Konferansı'nın Perde Arkası, Ankara, 2006, s.17; S.İ. Aralov, Bir Sovyet Diplomatının Türkiye Anıları, (Çvr.Hasan Ali Ediz), 2.bs., Ankara, 1985, s.1. 
meydana getirmeğe çalıştı. Lord Curzon, bu bağlamdaki çalışmalarında başarılı da oldu. Boğazların bütün yabancı savaş gemilerine kapatılması ve buranın güvenliğinin de Türkiye'ye bırakılması gerektiğini ifade eden Rus tezine karşı Türkiye, Sovyetler karşısında tek başına kalma endişesi taşımış ve Müttefiklerin "Boğazlar" üzerinde uluslar arası bir komisyonun denetimine bırakılması teklifini menfaatlerine uygun görmüş olması, Türk ve Sovyet bloğunda soğuk rüzgarlar estirdi. ${ }^{23}$

Türk-Sovyet ilişkileri, Lozan Konferansı sürecinde, yukarıda da ifade edildiği gibi, yaşanan bir takım anlaşmazlıklara rağmen ileriki yıllarda daha da güçlenerek devam etmişti. Konferansta Türk Delegasyon Başkanı İsmet Paşa ile Georgi Vasilyeviç Çiçerin'in Boğazlar meselesinde İngiliz Delegasyon Başkanı Lord Curzon'a karşı ortak tavır ve cephe kurmaya çalışmaları bu ilişkiler adına çok önemliydi. İleriki yıllarda da Sovyet Rusya'daki fiili durum Batılı devletlerce (1924'te Lenin'in ölüm yıl dönümü münasebetiyle) tanınmış olsa da Türk-Rus ilişkilerini sarsamamış, hatta bu dostluk daha da kuvvetlenerek gelişmişti ${ }^{24}$.

1925'li yıllar Türkiye Cumhuriyeti Devleti açısında oldukça sıkıntılı geçti. Özellikle Lozan'da çözümlenemeyen Musul Meselesi için Türkiye ve İngiltere'nin masaya oturduğu sıralarda Şeyh Said İsyanı'nın çıkması Türkiye'yi oldukça zor durumda bırakmıştı. Görüşmeler esnasında Türkiye'nin "Türklerle Kürtlerin beraber yaşamak isteği” şeklinde ortaya koyduğu tezi tutarsız kalmış ve İngiltere'nin elini güçlendirmiş ${ }^{25}$, Musul Sorunu'nun İngiltere'nin lehine çözülmesinde etkili olmuştu. ${ }^{26} \mathrm{Bu}$ gelişmelerin en önemli sonuçlarından birisi de Türkiye ve SSCB'nin yakınlaşmasına ortam hazırlamış olmasıyd ${ }_{1}{ }^{27}$

Bu yıllarda Avrupa ülkeleri arasında da işbirliği devresi başlamıştı. 30 Ağustos 1924'te Londra'da Almanya'nın Daves Planı'nı kabul etmesi ve yürürlüğe girmesi milletlerarası ilişkilerde bu devrenin başlamasına ivme katmıştı. Bu sürecin öncülüğünü Almanya'yı borçlardan kurtaran ve ekonomik refaha kavuşturan Dışişleri Bakanı Gustov Stresemann yapıyordu. Stresemann, Şubat 1925 'te Fransa, İngiltere ve İtalya'ya bir saldırmazlık paktı teklif etmiş ve bunun sonucunda İsviçre'nin Lokarno şehrinde Fransa, İngiltere, Almanya, İtalya, Belçika, Polonya ve Çekoslovakya'nın katılımıyla yapılan görüşmeler sonucunda 16 Ekim 1925 'te bu pakt

${ }^{23}$ Stefanos Yerasimos, Azgelişmişlik Sürecinde Türkiye-Dünya Savaşından 1971'e-, (Çvr )Babür Kuzucu , c.III, 6.bs., İstanbul, 1992,s.66-67. Konferans boyunca yaşanan tartışmalar için bakınız, M. Cemil Bilsel, Lozan, c.II, İstanbul, (Tarihsiz), s. 298-vd; Ali Naci Karacan, Lozan Konferansı ve İsmet Paşa, İstanbul, 1943, s.116- vd.

${ }_{24}^{24}$ Rifkı Salim Burçak, Siyasi Tarih Ders Notları, Ankara, 1984, s.153.

${ }^{25}$ Erol Kurubaş, Başlangıçtan 1960'a Değin Kürt Sorununun Uluslararası Boyutu, Ankara, 1997, s. 67.

${ }^{26}$ Wadie Jwaideh, Kürt Milliyetçiliğinin Tarihi-Kökenleri ve Gelişimi-, (Çvr.) İsmail çeken- Alper Duman, 2.bs., İstanbul, 1999, s.408.

${ }^{27}$ Kurubaş, Başlangıçtan 1960'a Değin..., 167; Yaşar Kalafat, Şark Meselesi Işı̆̆ında Şeyh Sait Olayı, Karakteri, Dönemindeki İç ve Dış Olaylar, Ankara, 1992, s. 206 
imzalanmış oldu. Böylece "Almanya - Fransa ve Almanya - Belçika arasında sınırlar kesin olarak tespit” edilmiş oldu ${ }^{28}$.

"Almanya'yı tekrar milletlerarası işbirliğine sokmuş olması bakımından Locarno Antlaşmaları önemli birer vesika teşkil ediyordu. Avrupa politika semalarında esen ümit rüzgarları bunların eseri olmuștu". Ayrıca Almanya'nın bu işbirliği sonucunda Milletler Cemiyeti'ne girmesi sürecini etkileyen önemli bir diplomatik başarı oldu ${ }^{29}$.

Lokarno süreciyle Almanya'nın diplomatik arenada işbirliği araması en çok Sovyet Rusya'yı endişelendirmişti. Bu süreci Sovyet Rusya, Milletler Cemiyeti adı altında Kapitalist dünyanın proleteryaya yani kendisine karșı bir cephesi olarak görüyordu. Bunun için de Rusya, bu bloğa karşı kendi komşularıyla iyi ilişkiler kurmanın yollarını aramaktaydı. Türkiye açısından da durum pek iç açıcı değildi. Uluslar arası arenada yalnız kalan Türkiye'de bu yakınlaşmayı önemsiyordu. Özellikle Lozan'da çözüme kavuşturulamayan Musul Meselesi'nin İngiltere'nin tesiriyle Milletler Cemiyeti Konseyi'nde bu bölgenin Irak'a ait olduğuna dair 16 Mart 1925'de karar verilmesi Türkiye'nin batılı devletlerle olan ilişkilerini çok germiş, daha da ileri gidilmiş; hem İtalya, hem de İngiltere Türkiye'ye karşı tehditler savurmaya başlamıştı.

İşte bu siyasi atmosfer Türkiye ve Sovyet Rusya'yı birbirine yaklaştırmıştı. "Milletler Cemiyeti'nin kararı Türkiye'de İngiltere'ye karşı bir savaş havası yarattı" ${ }^{30}$. Milletler Cemiyeti'nin Musul kararından bir gün sonra yani 17 Aralık 1925 tarihinde Türkiye'nin bu karara dolaylı cevabı mesabesinde olacak olan Sovyet Dışişleri Bakanı Çiçerin ile Türkiye Dışişleri Bakanı Dr. Tevfik Rüştü Bey arasında Paris’te yeni bir dostluk ve tarafsızlık antlaşmasının imzalanması idi ${ }^{31}$.

Bu tarihten sonra Rusya'nın önce Türkiye ile sonra da Avrupalı birçok devletle "saldırmazlık ve dostluk antlaşmaları" imzalanmasının en önemli sebebini de Armaoğlu şöyle izah etmektedir. "Sovyet Rusya, Batılılardan duyduğu bu korku ve Locarno'ya karşı bir tepki olarak etrafını çevreleyen devletlerle bir saldırmazlık ve tarafsızlık politikasına girişti. Önemli olan,

28 "Bu andlaşmanın imzalanmasında büyük hizmetleri görüldüğü için o tarihteki İngiltere Dıșişleri Bakanı Chamberlian, Fransa Dıșişleri Bakanı Briand ve Alman Dışş̧ıleri Bakanı Stresemann'a Nobel ödülü verildi” Orhan Melih Kürkçüer, Siyasi Tarih (1789-1960), 5.bs, Ankara, 1972, s.153.

${ }^{29}$ Reșat Sagay, XIX. ve XX. Yüzyıllarda Büyük Devletlerin Yayılma Siyasetleri ve Milletlerarası Önemli Meseleler, İstanbull, 1972, s.299.

${ }^{30}$ Ömer Kürkçüoğlu, Türk-Ingiliz İlišileri (1919-1926), Ankara, 1978, s.300.

${ }^{31}$ Burçak, Siyasi Tarih, s.154. "1925'te yeniden imzalanan bir anlaşma ile taraflar:

1-Birbirlerine taarruz etmeyeceklerini

2-Taraflardan biri bir tecavüze uğrarsa ötekinin bî taraf kalacağını,

3-Üçüncü bir devlet ile birbirleri aleyhine bir ittifaka girmeyeceklerini,

4-Münazaaları aralarında olmazsa Cemiyet-i Akvam vasıtasiyle müslihane halledeceklerini,

5-Antlaşmanın 3 sene yürürlükte kalacă̆ını... kabul ediyorlardı”. Tahsin Ünal, Türk Siyasi Tarihi (1700-1958), 5.bs., Ankara, 1978, s.581. 
kendisine komşu olan devletlerin Batılıların bir saldırısına alet olmaması ve Sovyet Rusya'nın Batılılardan herhangi biriyle çatışma halinde bu komşu devletlerin tarafsız kalmaları idi" ${ }^{2}$. 17 Aralık 1925 tarihli Türk-Sovyet Paktı sürecini Rıfkı Salim Burçak, P.Milioukof'tan şu ilginç cümle ile aktarır: "Bu antlaşma tarafların Milletler Cemiyeti'ne girmemeleri hususunda zımnî bir taahhüdü de ihtiva ediyor" ${ }^{\prime 33}$.

Türk-Sovyet politikaları bu süreci yaşarken milletler arası işbirliği devresinde de dikkat çekici bir adım daha atılır. Bu, Paris Paktı olarak da bilinen Briand-Kellog Paktı'nın imzasıydı. Locarno'dan sonra Fransa Dışişleri Bakanı Briand, hem Fransa hem de dünyada kalıcı barış yolları aramıştı. Özellikle Almanya'da faşizan hareketlerin yükselişi ve Versailles Antlaşması'nın yeniden gözden geçirilmesi yönündeki beklentiler onu yeni arayışlara itmişti ${ }^{34}$.

Nisan 1927'de Fransa Dışişleri Bakanı Briand, ABD'nin Birinci Dünya Savaşı'na katılışının onuncu yıl dönümünde Amerikan milletine bir beyanname yayınlayarak her iki devlet arasındaki sorunların barış̧̧ı yollarla halledilmesi gerektiğini, savaşın çıkmaması için ne gerekiyorsa yapılsın şeklindeki vurgusuna ABD Dışişleri Bakanı Kellog, olumlu cevap vermiş ve sonunda 27 Ağustos 1927 yılında birçok dünya devletinin katılımıyla bu pakt imza edilmişti ${ }^{35}$.

Bu pakta Sovyet Rusya ve Türkiye'de davet edilmiş ve her iki devlet de bu pakta imza atmış oldu. Dolayısıyla da milletlerarası işbirliği devresine ters düşmek istememiş olduklarını ifade etmek istemişlerdi.

Sovyet Rusya ile imza edilen Saldırmazlık Paktı'ndan sonra Türkiye Dışişleri Bakanı da Odessa'ya giderek Sovyet Dışişleri Bakanı ile görüşmüş, ilişkilerde gelinen aşama değerlendirilmiş ve dostluk konusunda Türk tarafının samimi duygularını dile getirilmişti.

İleriki yıllarda Cenevre'de toplanacak olan silahsızlanma konferansına da Türkiye Maksim Maksimoviç Litvinof'un çabalarıyla davet edilmişti. Bu davet ile Lozan'dan sonra ilk defa Türkiye uluslar arası işbirliğine çağrılmış oldu. Bu konferansa davet Türkiye'nin Batı ile olan ilişkilerinde yeni pencereler açacak, dahası Milletler Cemiyeti'ne girmesine büyük kolaylıklar da sağlayacaktı. Türk-Sovyet ilişkilerinde gelinen nokta beraberinde Türkiye'ye diğer dünya devletleriyle olan ve olacak olan ilişkilerine de tesir ederek dış politikada Rusya'ya bağımlı olmaktan sıyrılarak daha bir özgün ve realist politikalar geliştirmesine imkan verecekti.

Türkiye'nin uluslar arası düzlemde konumunun iyileşmesiyle Sovyetlerin İngiltere ile olan ilişkilerinin bozulması, buna rağmen Türkİngiliz ilişkilerinde alınan mesafeler özellikle İngiliz donanmasının

\footnotetext{
${ }^{32}$ Fahir Armaoğlu, 20.Yüzyıl Siyasi Tarihi (1914-1990), C.I; Ankara, 1991, s.168.

${ }^{33}$ Burçak, Moskova Görüşmeleri, s.14.

${ }^{34}$ Sagay, XIX. ve XX.Yüzyıllarda, s. 300.

${ }^{35}$ Kürkçüer, Siyasal Tarih, s.154-55.
} 
Türkiye'yi ziyareti ve Türkiye'de Komünist ideolojiye karşı ortaya çıkan yeni tavırlar gibi gelişmeler Sovyet Rusya'yı endişelendirmeye yetmiş̧ $\mathrm{t}^{36}$. Bu gerçekçi duruma rağmen 1925 antlaşmasıyla elde edilen kazanımları sarsılmaz dostluk hissiyle Türkiye'ye bizzat ifade etmek üzere Sovyet Dışişleri Bakan Yardımcısı Karahan, Ankara'ya geldi. 17 Aralık 1929'da da yeni bir protokol imza edilmiş ve Dostluk Andlaşması üç yıl daha uzatılmış oldu $^{37}$.

Karahan'ın ziyaretinin estirdiği olumlu hava devam ederken, Türkiye'nin Dışişleri Bakanı Dr.Tevfik Rüştü Bey de iade-i ziyaret babından Ekim 1930'da Moskova'ya gitti. Burada SSCB Dışişleri Halk Komiseri Litvinov'la ilişkiler ve sorunlar üzerine görüşmeler yaptı. Bu görüşmelerde Litvinov: "Sovyet ve Türk diplomasinin barış uğrundaki savaşta işbirliği bugünkü koşullarda son derece büyük sorumluluk isteyen tarihsel bir görevdi" vurgusunu tekrarlamaktaydı. Bu mesajlara karşıllı Tevfik Rüştü Bey de "Dünya politikasının gelişimiyle ortaya çıkan dostluğumuza bağlı kaldığımızı unutmak mümkün mü?’”38 diyerek gelinen noktayı ifade etmişti.

Türkiye'nin Batıyla olan temasları karşısında endişelenen Rusya, tabir-i caizse irtibatı koparmak istemez. Bu ziyaretten sonra Litvinov, 16 Mart 1931 tarihinde Türk Dışş̧̧leri Bakanı Tevfik Rüştü Bey’e bir dostluk mesajı daha yollayarak 1921 tarihli Moskova Antlaşması'nın 10. yıldönümünü kutlamış ${ }^{39}$ 27 Ekim 1931 tarihinde de Türkiye'yi ziyaret etmişti. Bu ziyaret Türkiye'nin Milletler Cemiyeti'ne üyeliğinin tartışıldığı bir döneme denk geldiği için büyük ilgi toplamıştı. Özellikle İngiltere bu ziyareti yakın takibe almıştı. Ziyareti daha çok ekonomik nedenlerden dolayı Batıya yaklaştığı şeklinde değerlendiren Sovyet Rusya, Litvinov'un ziyaretiyle Türk ve dünya basınına ve kamuoyuna Sovyetlerin Türkiye'ye her türlü ekonomik yardımı yapabilecek güçte olduğu mesajını vermek istediği şeklinde yorumlamıştı ${ }^{40}$.

Litvinov ziyaretinin ardından iade-i ziyaret olarak Sovyet Rusya'nın daveti üzerine bu sefer Türkiye Başbakanı sıfatıyla İsmet Paşa ve heyeti, Mayıs 1932 tarihinde Moskova'yı ziyaret etti.

Heyet, Moskova'da törenlerle karşılanmış ve en iyi şekilde ağırlanmıştı. Bu ziyarette ekonomik ve kültürel alanda birçok görüşme yapılmış, dostluk

\footnotetext{
${ }^{36}$ Ahmet Şükrü Esmer, “Türk Diplomasisi (1920-1955)”, Yeni Türkiye, İstanbul, 1959, s.78.

${ }^{37}$ Esmer, "Türk Diplomasisi (1920-1955)", s.78-9; Burçak, Moskova Görüşmeleri, s.14-15. Bu protokolde su ifadeler yer alır: "Akitlerden her biri diğer tarafa iblağ etmeksizin işbu tarafın kara veya denizden doğrudan doğruya komşuluğunda bulunan devletlerle siyasi mukaveleler akdine matuf müzakerelere girişmemeği ve bu kabil mukaveleleri ancak mevzu bahis tarafın muvaffakatı ile akdetmeyi taahhüd eder". Burçak, Siyasi Tarih, s.155.

${ }_{38}$ SSCB Bilimler Akademisi, Ekim Devrimi Sonrası Türkiye Tarihi, Cev. A.Hasanoğlu, c.I, İstanbul, 1978, s.201s

${ }^{39}$ Hasan Berke Dilan, Atatürk Dönemi Türkiye'nin Dış Politikası (1923-1939), İstanbul, 1998, s.97.

${ }_{40}^{40}$ Türk Diş Politikasının Analizi, (Der. Faruk Sönmezoğlu), 2.bs, İstanbul, 2001, s.85.
} 
mesajları verilmiş ${ }^{41}$ Türkiye'nin Milletler Cemiyeti'ne girmesi süreci ve desteği de sağlanmış oldu.

\section{C-Kliment Yefromoviç Voroşilov Heyetinin Türkiye'yi Ziyareti}

\section{1-Voroşilov Heyeti'nin Türkiye'ye Gelişi}

SSCB ile Türkiye arasındaki ikili ilişkilerin artarak devam ettiği görülmekteydi. Cumhurbaşkanı Gazi Mustafa Kemal, TBMM dördüncü dönem üçüncü toplanma yılı münasebetiyle yaptığı konuşmasında Sovyet Rusya'ya bakışı ve gelinen noktayı şu şekilde ifade etmekteydi: "Efendiler! Bu sene, mümtaz bir Sovyet Heyeti'nin cevap ziyaretini kabul ettik (alkışlar). Bu ziyaretin onuncu yıl bayramına tesadüf ettirilmesi, iki memleket arasındaki münasebetlerin derin samimiyetini gösteren mesut bir vesile olmuştur (alkışlar)

İki memleketin çetin zamanlarında kurulmuş, on beş senedir türlü imtihanlardan daha kuvvetli çıkmış bir dostluğun daima yüksek kıymeti haiz olması, beynelmilel sulh için değerli ve ehemmiyetli bir amil olduğundan tereddüd edilemez (alkışlar) ${ }^{, 42}$.

İsmet Paşa'nın Moskova'yı ziyaretinden sonra 1933 yılında iade-i ziyaret etmek üzere SSCB Başkanı Vyaçeslov Mihayloviç Molotov'un Ankara'yı ziyareti kararlaştııılmışı ${ }^{43}$. Bu sırada Molotov hastalanmıştı. Bu beklenmedik duruma rağmen ziyaret ertelenmemiş ${ }^{44}$ sadece katılacak heyette bir takım değişiklikler olmuştu. Bu durum Türk basınına da şu şekilde haber olmuştu: "İcra Komiserleri Reisi Molotof gribe tutulmuştur, hekimler seyahatine müsaade etmemektedirler. Molotof'un rahatsızlığı haberi bizi müteessir etmiştir. Rus devletinin bu büyük şahsiyetinin bu seferki ziyaretinden mahrum olacaksak da herhalde bir müddet sonra memleketimizde selamlamak ümidiyle müteselli oluyoruz.

Rus heyetine, Sovyet Rusya'nın namdar bir şahsiyeti, Kızıl Ordu'nun Başkumandanı Harbiye Komiseri Voroșilof yoldaş reislik etmekte ve M. Molotof'un vekili olarak gelmektedir" ${ }^{\circ 5}$.

Sovyet Başbakanı Molotof'un beklenmedik rahatsızlı̆̆ı karşısında programdaki değişiklik nedeniyle Türkiye Başbakanı İsmet Paşa'ya bir telgraf çekerek duyduğu üzüntüyü ifade etmişti. Bu telgrafta şu ifadeler yer almıştı: "Türkiye Cumhuriyeti'ni, onuncu yıl dönümünde tesidi gününde ziyaret hususundaki eski arzumu tahakkuk ettirmek imkansızlığına çok müteessirim. Müessif bir rahatsızlık, zatı devletlerini tekrar görmekliğimiz ve derin intibaını muhafaza ettiğim Moskova'da yaptığımız mükalemeleri ve

${ }^{41}$ Bu ziyaret vesilesiyle "Sovyet Hükümeti, Türkiye'ye karşıllğı mal olarak ödenecek olan 8 milyon dolarlık uzun süreli faizsiz kredi açtı..." Ekim Devrimi Sonrası Türkiye Tarihi, s.202.

${ }_{42}$ Atatürk'ün Söylev ve Demeçleri, C.I-III, Ankara, 1997, s.392.

${ }^{43}$ Kamuran Gürün, Türk-Sovyet İlișkileri ( 81920-1953), Ankara, 1991, s.132.

${ }^{44}$ Dilan, Atatürk Dönemi, s.100.

${ }^{45}$ Hâkimiyet-i Milliye, 24 Birinci Teşrin/Ekim 1933, No:4406. 
zat-1 devletlerine olan en iyi hislerimi tekrarlamaklığıma mani oluyor. Türk milleti ve hükümeti'nin Türkiye Cumhuriyeti'nin onuncu yıldönümü bayramına bizzat iştirak edemeyeceğime ve şahsen tebrikatta bulunamayacağıma fevkalade müteessirim. Türkiye Cumhuriyeti'nin onuncu yıldönümü münasebetiyle şimdiden tebriklerimi arz ederim. Yeni Türkiye'nin yalnız Türk milleti için değil, fakat aynı zamanda Türkiye'nin bütün hakiki dostları için de medar-1 iftihar olan muvaffakiyetlerinden duyduğum sevincin ifadesini kabul ediniz. Derin muhabbet ve dostluk hislerimin kabulünü rica ederim" ${ }^{46}$.

$\mathrm{Bu}$ telgrafa karşılık İsmet Paşa da bir telgrafla cevap vermişti. Bu telgrafta da "Nazikane eseri dikkatinizden ve Türkiye Cumhuriyeti'nin onuncu yıldönümü münasebetiyle bana yapmak lütfunda bulunduğunuz tebriklerden dolayı hararetli teşekkürlerimi zati devletlerine tekrar ederken yakında görüşmek üzere muhabbetimin ve samimi dostluğumun ifadesini gönderiyorum" demişti ${ }^{47}$.

İsmet Paşa'nın 1932 yılında gerçekleştirdiği Moskova ziyaretine cevap olmak üzere Molotov yerine Voroşilov heyetinin geleceği belirlenince gerekli diplomatik hazırlıklar da başlatılmıștı. Voroşilov'un Türkiye ziyaretinin hem Türkiye'de hem de dünyada büyük yankılar uyandırmış olmasi $^{48}$ ev sahibi olarak Türkiye'yi heyecanlandırmış ve iyi bir misafirperverlik için hiçbir fedakarlıktan kaçınılmamıştı.

Türkiye'de cumhuriyetin ilanının onuncu yıldönümü anısına resmi bir ziyaret yapacak olan Varoşilov heyetinde kendisinden başka "Dışişleri Halk Komiser Yardımcısı Karahan, Eğitim Halk Komiseri Bubrov, Eğitim Halk Komiser Yardımcısı Krjijanovski, SSCB Süvari Kuvvetleri Komutanı ve Devrimci Askeri Sovyet Üyesi Budiyanni" ${ }^{\text {"49 }}$ bulunacaktı.

${ }^{46}$ Milliyet, 26 Teșrîn-i Evvel/Ekim 1933, No:2770

47 İsmet İönü, Konuşma, Demeç, Makale, Mesaj ve Söyleşiler (1933-1938), Haz.İhan Turan, Ankara, 2003, s.1.

${ }^{48}$ Mesela Londra'da çıkan Evening Standard gazetesi bu ziyareti haber yapmıștı. Başbakanlık Cumhuriyet Arşivi (B.C.A), 030.10.241.630.14, Varak No:1

${ }_{49}$ Mehmet Perinçek, Atatürk'ün Sovyetlerle Görüşmeleri (Sovyet Arşiv Belgeleriyle), İstanbul, 2005, s.214-215. Voroşilov ve heyetinde bulunan Sovyet Rusya'nın seçkinlerinin Türk basınına yansıdığı kadar hayat hikayeleri şöyledir:

"Voroşilov:

1881 'de bir yol amele ailesinden doğmuştur. Yedi yaşından itibaren çobanlık, maden ameleliği, fabrika işçiliği yapan Voroşilof daha gençliğinde Donetz havzasında amele ihtilâlinin ön safına geçmişti. Birçok defa hapis ve tehcir edilen Vorolişoff, Şubat İhtilâli'nde Petrograt'ta da ihtilâlci amelenin başına geçmiştir.

Ihtilâl tekemmül edince 1918 'den itibaren orduda vazife almıştır.Ukrayna'daki mukabil ihtilâl zamanında onuncu ordu başında Stalingrad'ı kahramanca müdafaa etmiştir.

1919'da birinci süvari ordu meclisi harbine aza seçilmiş ve bu ordunun siyasi şefi olmuştur.

Budenny ile birlikte șimdi dünyada emsalsiz kuvvette olan tabiyevi süvari teşkilatı vücuda getirmiştir. Bu ordunun başında Denikin ve Verangel kıtaatını hezimete uğratmıştır: ondan sonra Şimali Kafkasya'da, Moskova'da muhtelif askeri vazifelerde bulunmuştur. Voroşilov 1925 'ten beri Harbiye ve Bahriye Komiserliklerinde bulunmaktadır. Voroșilof'un idaresi altında Rus ordusu bugün dünyanın en kuvvetli ordusu olmuştur.

Budenny: 
Bu sırada Voroşilov ve heyetinin programı da belirlenmişti. Buna göre misafirleri getirecek olan İzmir Vapuru, askeri mihmandar ve Dışişleri Bakanlığı Özel Kalem Müdürü 24 Ekim'de Sivastopol'da olacak, 25 Ekim'de misafirler Sivastopol'dan hareket edecek ve İstanbul'a geleceklerdi. İzmir Vapuru iki torpido muhbiri ile bir tayyare filosu boğaz methalinde karşılaşacak ve limana kadar kılavuzluk edecekti ${ }^{50}$.

Voroşilov ve Sovyet heyeti Sivostopol İstasyonu'nda Türkiye'nin Moskova Sefiri Hüseyin Ragıp Bey, Muzaffer Paşa ve Türk Askeri Heyeti, Dışişleri Bakanlığı Özel Kalemi Müdürü Refik Amir Bey ve Sovyetlerin Ankara Sefiri Suriç tarafından karşılanmış ve İzmir Vapuru ile İstanbul'a hareket edilmişti. 26 Ekim tarihinde İzmir Vapuru Türkiye sahillerine yaklaşırken Voroşilov, Başvekil İsmet Paşa'ya vapurdan şu telgrafı gönderir:

(Simeon Mikailovitch Budenny'nin Türkiye'ye ilk gelişi 1919 yılı Mayıs ayıdır. Mustafa Kemal Paşa Samsun'a çıktıktan sonra Budenny ile Havza'da görüsmüștü.Daha genis bilgi için bakınız Hüsameddin Ertürk, İki Devrin Perde Arkası (Yazan Samih Nafiz Tansu), İstanbul, 1964, s.338-vd.)

'Simeon Mikailovitch Budenny, 1883 'te bir köylü ailesinden doğmuștur. Kendi başına yazıp okumasını öğrenmiş ve 9 yaşında ziraat ameleliği ile hayata atılıştır. Rus-Japon muharebesine nefer olarak, Umumi harbe de çavuş olarak iștirak etmiștir.

1917 Şubat İhtilâli'nde Budenny askerler arasında ihtilal işlerini idare etmiştir. 1919'da Komünist F̧ırkası'na aza olmuştur. Dahili Harbin başlangıcında bizzat teşkil ettiği süvari kıtaatının başına geçmiş ve bu suretle Beyaz Ruslara karşı birçok muvaffakiyetler elde ederek Denikin ve Varangel ordularının hezimetine yardım etmiştir.

$\mathrm{Bu}$ ordunun şekli, hala bir çok memleketler askeri mütehassısları tarafından tetkik edilmektedir. Kızıl ordunun asrileştirilmesinde Budenny'nin de büyük hissesi vardır.

Krijanovski:

Maximilianovicz Krijanovski, 1872'de doğmuştur. Gençliğinden beri kendisini ihtilale hasretmiştir: Memleketini elektrikleştirmek sahasındaki hizmetleri büyüktür. Sovyetler mevkii iktidara gelip 1918 'de Lenin memleketin elektrikleştirilmesi işini düşündüğü zaman mumaileyh bu işlerin idaresine memur edilmiştir:Beş senelik planın mürettibi kendisidir. Bu plan elyevm tahalluk etmiș bulunuyor. Krijanovski şimdi memleketin yeni elektrikleștirilmesi gibi muazzam bir işin başında bulunmaktadır. Sarfettiği mesaiden dolayı Lenin nişanı ile taltif edilmiştir. Fenni faaliyetinden dolayı Sovyet Fen Akademisi azalığına seçilmiştir. 1932 Maarif Komiserliği muavinliğine tayin edilmiștir. Milliyet, 24 Teșrîn-i Evvel/Ekim 1933.

Boubnov:

Andre Sorguievitch Boubnov 1883 'te doğmuștur. 17 yașında iken talebe ihtilâl teşkilatı ile temasa geçmiştir. 1903'te Komünist Fırkası'na girmiştir.Çarlık devrinde birçok defalar tevkif edilmiştir. İhtilal zamanında hazırlıklara faalane surette yardım etmiştir.Çar Polisi tarafından şiddetle takip olunmuștur. Bir çok kereler tevkif edilmiştir.

1912'de komünist fırkası kendisini namzet göstermiştir. Teşrin ihtilalînde hükümet darbesinin hazırlıklarına ve muvaffakiyetine faaliyetle iştirak etmiștir.

İhtilâlden sonra mukabil ihtilâl kuvvetlerine ve Alman işgal kuvvetlerine karșı mücadele etmiştir. Beyazların tardından sonra Kiyef Şuraları Reisi intihap edilmiş ve Ukrayna Hükümeti'ne dahil olmuştur. 1922-23'te Rusya propaganda teşkilatının başına geçmiştir. 1924 'te Kızılordu'da siyaset şubesi müdürlüğüne ve Rusya Askeri İhtilâl Şurası azalığına tayin ediliştir.

1929 'da Rusya Cumhuriyeti Maarif Komiserliği'ne tayin edilmiş ve mecburi tahsil programını tatbik ederek "ümmilikle mücadele" işini başarmıștır. Aynı zamanda Sovyet Komünist Fırkası Merkez Komitesi'nin teşkilat bürosunda aza sıfatıyla çalışmıştır.

M.Bubnow, ihtilâl edebiyatına ve iktisadiyatına ait birçok eserler yazmıştır. Sovyet Komünist Fırkası tarihine ait de birçok kitapları vardır". Hâkimiyet-i Milliye, Birinci Teşrin/Ekim 1933

${ }^{50}$ B.C.A. 030.10.198.352.14, Varak No:1. 
“Türkiye sahillerine yaklaşırken, yakında yapacağımız ve milletlerimiz arasındaki sarsılmaz dostluğu daha ziyade kuvvetlendireceğine emin bulunduğumu telakki münasebetiyle derin memnuniyetimi zatî devletlerine arz etmekle bahtiyarım. Samimi selamlarımın kabulü zati devletlerinizden rica ederim. Başvekil Hazretleri" ${ }^{51}$.

Sovyet Heyeti'ni getiren İzmir Vapuru 8.30'da Boğaz açıklarına gelmiş ve iki Türk torpidosu vapuru karşılamıştı. Vapur Büyükdere Mevkii'ne geldiği vakit Vali ve Belediye Başkanı Muhittin Bey, Kolordu Kumandanı Şükrü Naili Paşa, Dışişleri mihmandarları vapuru burada karşılamışlar ve vapura çıkarak misafirlere hoş geldiniz demişlerdi. Vapur boğazdan geçerken iki sahil boyunca biriken İstanbul halkı heyeti büyük tezahüratlarla karşılamıştı. Sonra misafirler Tophane rıhtımına çıkmışlar ve burada Vali Muavini, Emniyet Müdürü tarafından karşılanmışlardı. Rıhtımda askerî merasim yapılmış ve Sovyet marşı çalınmışt $1^{5^{32}}$.

Bu karşılama töreninden sonra misafirler, otomobillerle dinlenecekleri Pera Palace Oteli'ne gitmişti. Misafirler daha sonra İstanbul Vali, Belediye Başkanı'na ve Kolordu Komutanı'na iade-i ziyarette bulunup, basına da birtakım beyanatlar vermişlerdi ${ }^{53}$. Saat 13.45 'de ise Vali ve Belediye Reisi, Pera Palace Oteli'nde misafirlerin şerefine bir öğle yemeği verdi ${ }^{54}$.

Ziyarete basının ilgisi çok büyük olmuştu. Bu maksatla Falih Rıfkı, köşesinde "Büyük Dostlara Selam" başlığıyla bir yazı kaleme aldı. Bu yazısında; "ikisini (Mustafa Kemal ve Lenin) de dünya inkâr ve tecrit ederken, Leninizm ve Kemalizm birbirlerine inandılar ve mefkûre mücadelesinin yılmaz, yıkılmaz, yenilmez ve düşürülmez irade ve iman ateşi içinde kaynaştılar. Moskova'nın onuncu yıldönümü bayramı bizim de bayramımızdı. Ankara'nın onuncu yıldönümü bayramının Stalin'in memleketinde de aynı his ile karşılandığından eminiz" ${ }^{\prime \prime 5}$.

Necmeddin Sadık ise Akşam Gazetesi'ndeki köşesinde "Hoş Geldiniz Çok Aziz ve Kıymetli Misafirlerimiz" başlığıyla yazdığı makalesinde TürkRus dostluğunun iki memleket içinde faydalı dahası zaruriyetine vurgu

${ }^{51}$ Voroşilof'un bu telgrafına İsmet Paşa cevaben şu telgrafı çeker: "İzmir Vapuru’nda gönderdiğiniz sevimli telsiz telgrafından dolayı size hararetle teşekkür ederim. Yarın sizi Ankara'da tekrar görmek fikriyle bilhassa bahtiyarım. Keza mülakatımızın milletlerimiz arasında mevcut olan sarsılmaz dostluğu daima daha ziyade kuvvet bulmasına medar olacağına dair derin bir kanaatim vardır...” Hâkimiyet-i Milliye, 27 Birinci Teşrin/Ekim 1933; İsmet İnönü, Konusma, Demeç, Makale, Mesaj ve Söyleșiler...”, s.2.

52 Hâkimiyet-i Milliye, 27 Birinci Teşrin/Ekim 1933. Sovyet Hükümeti bu ziyaret anısına Türk ordusuna dört tane tayyare hediye etmiş ve bunlar Yeşilköy'e nakledilmişti. Burada parçalar kurulacak ve tayyareler denendikten sonra Ankara'ya gideceklerdi Hâkimiyet-i Milliye, 25 Birinci Teşrin/Ekim 1933.

53 "Voroşilof basına şu beyanatı vermişti. "Bu vazifeyi büyük bir sevinçle kabul ettim. Bu vazifenin yerine getirilmesi hususunu, büyük Türkiye Cumhuriyeti'nin reisine tebriklerimizi bizzat ve çok manalı bir ehemmiyeti haiz böyle bir günde Türk milletinin sevincine iştirak etmek imkanını bana vereceğinden dolayı da derin bir bahtiyarlık duyuyorum..." Akșam, 27 Teșrîn-i Evvel/Ekim 1933.

${ }^{54}$ B.C.A., 030.10/198.352.14, Varak No:1-2.

${ }^{55}$ Perinçek, Atatürk'ün Sovyetlerle Görüşmeleri, s.215. 
yapmıştı. Bu dostluğun yalnız iki ülke halkına barış getirmediğini, aynı zamanda “Avrupa'nın şarkında daha şümullü bir sulh anlaşmasının başı, yeni bir müvazenenin kaynağı olmuştur. Bilhassa son senenin siyasi tarihine göz atılırsa, gerek beynelmilel konferanslarda, gerek daha umumî ve devamlı sahalarda Sovyet-Türk çalışma birliğinin hem kendi memleketlerimize, hem Avrupa sulhüne temin ettiği semerelerin derhal dikkate çarpacak kadar büyük olduğu anlaşılır" olduğunun altını çizmişti ${ }^{56}$.

Mehmet Asım Bey de Vakit Gazetesi'nde "Dün Gelen Misafirlerimiz" isimli yazısında "Büyük komşumuz Rusya, Türk Milleti'ne en felaketli günlerinde dostluk elini uzatmıştır. Diğer taraftan Türk Milleti, Rus dostluğunu bütün dünyanın Rusya'nın aleyhine dönmüş olduğu günlerde bile muhafaza etmiş" diyerek kurulan dostluğun önemini vurgulamışt1 ${ }^{57}$.

İstanbul'daki karşılamanın ve ziyaretlerin ardından program gereğince misafirler bir otomobille İstanbul'u dolaşmışlardı. Ve 19.30'da özel bir tren ile Ankara'ya hareket edileceğinden Tophane Rıhtımı'ndan Haydarpaşa'ya hareket edilmişti. Misafirlerin trenle Ankara'ya gideceğini öğrenen İstanbullular gara saatler öncesinde gelmişlerdi. Misafirler halkın büyük tezahüratları ve "Yaşasın dost Sovyet hükümeti" sesleri arasında karşılanmışlardı. Burada milli marşların çalınmasından sonra Voroşilov, karşılamaya gelenleri selamlamış ve vagonun balkonundan karşılamaya gelenlere hitaben şunları söylemişti:

"Size dost Sovyet Rusya'nın candan selamını ve temennilerini getirdim. Size kardeş Rus ordusunun yenilmez Türk ordusuna selamlarını getirdim" "58 demiş müteakiben de trenle Ankara'ya uğurland.

\section{2-Heyetin Ankara'ya Gelişi}

Heyetin Ankara ziyareti dört gün sürecekti. 27 Ekim 1933 Cuma günü heyeti taşıyan özel tren 10.30 'da Ankara İstasyonu'na vasıl oldu. İstasyon Türk ve Sovyet bayraklarıyla donatılmış, misafirleri karşılayacak devlet protokolü de yerlerini almıştı. Protokolde Başvekil İsmet Paşa, Milli Müdafaa, Hariciye Vekilleri ve eşleri CHP Katip-i Umumisi, Parti'nin yöneticileri ve eşleri, Birinci Ordu Komutanı ve eşi, Başvekalet Müsteşarı, Ankara Valisi, Belediye Reisi ve eşleri ile vekaletlerin müsteşarları ve diğer görevliler bulunmaktaydr ${ }^{59}$.

\footnotetext{
${ }^{56}$ Necmeddin Sadık; "Hoş Geldiniz Çok Aziz ve Kıymetli Misafirlerimiz" Akşam, 26 Teşrîn-i Evvel/Ekim 1933.

${ }^{57}$ Mehmet Asım, "Dün Gelen Misafirlerimiz", Vakit, 27 Birinci Teșrin/Ekim 1933. Cumhuriyet gazetesinin başyazarı Yunus Nadi'de yazısında şunları diyordu: "Yeni Türkiye'deki inkılâp hayatı ile yeni Rusya'daki inkılâp heyetine başka delil bulunamasa iki memleketin bu kuvvetli dostlukları ve cihanın bu tarafında pek mühim hediyeler vuku bulmus olduğunun en parlak misalini teşkil eder..." Yunus Nadi, "Çok Kıymetli Rus Misafirlerimiz", Cumhuriyet, 27 Teşrîn-i Evvel/Ekim 1933.

${ }^{58}$ Vakit, 27 Birinci Tessrin/Ekim 1933.

${ }^{59}$ B.C.A, 030.10/198.352.14, Varak No:2.
} 
Trenin gelişiyle birlikte heyeti Başvekil İsmet Paşa ve Erkân-1 Harbiye Reisi Fevzi Paşalar karşılamış, Voroşilov, Rus milleti ve hükümeti namına Türk milletini ve ordusunu selamladığını ifade etmişti. Müteakiben de halkın alkışları arasında ikamet edecekleri Ankara Palas Oteli'ne gitmişlerdi. Heyet bir müddet burada dinlendikten sonra Başvekil İsmet Paşa'y1, Hariciye Vekili Tevfik Rüştü Bey'i, Meclis Başkanı Kâzım Bey ve Erkân-ı Harbiye Reisi Fevzi Paşaları toplu olarak ziyaret etmişlerdi ${ }^{60}$.

Bu ziyaretlerin ardından program gereğince saat 17.00 'da misafir heyet Cumhurbaşkanı Mustafa Kemal Paşa tarafından kabul edildi. Kabulde heyetin dışında Dışişleri Bakanı Tevfik Rüştü Bey’le Sovyetlerin Ankara Büyükelçisi M.Suriç ve Türkiye'nin Moskova Büyükelçisi Hüseyin Ragıp Bey, Ankara Valisi Nevzat Bey ve erkan da hazır bulunmuştu ${ }^{61}$. Mustafa Kemal Paşa'nın bu kabulünde daha önce gündemde olan Lozan Boğazlar Sözleşmesi'nin Boğazların silahsızlandırılması noktasındaki durumunun Türkiye lehine değiştirilmesi girişimlerine tesadüf etmişti. İşte bu görüşmelerde en çok konuşulan konu da Sovyetlerin Türkiye'ye daha çok destek vermesi mesajlarıydi ${ }^{62}$.

Resmi ziyaretlerin akabinde akşam 20.30 'da misafirlerin şerefine Başvekil İsmet Paşa, bir ziyafet vermiş ve Paşa, yemeğin sonunda bir de konuşma yapmıștı. Bu konuşmasında daha milli mücadele yıllarında Sovyet Rusya ile başlayan dostluktan ve kendisinin 1932 yılında Moskova'ya yaptığı ziyarete dair hatıralarından övgü ile bahsetmişti ${ }^{63}$.

İsmet Paşa'nın bu konuşmasına cevaben Voroşilov, ziyaret münasebetiyle Türkiye'de gördüğü samimi ortamı övmüş ve konuşmasına şöyle devam etmişti: "Başvekil Hz. milletimizin birbirine gayet sıkı dostluk bağlarıyla bağlı olması, keyfiyeti bütün cihana malumdur ve hiçbir yerde ve hiçbir kimsede şüphe uyandırmamaktadır" ${ }^{64}$ diyerek bu dostluğa bir kez daha vurgu yapmıştı. "Türk Milleti'nin kahramanca yaptı̆̆ı kurtuluş mücadelesini övüyor, ekonomik ve kültürel bağların kuvvetlendiğini belirtiyordu. Ufukta görünen saldırı niyetleri karşısında savunma olanaklarının artırılmasının üzerinde duruyor. Tüm silahsızlanma önerilerinden sonra ilk defa Voroşilov, bu iki memleket ordularının güçlerinin artırılmasından ve gelişmesinden söz ediyordu" 65 .

${ }^{60}$ Vakit, 28 Birinci Tesrin/Ekim 1933.

${ }^{61}$ Milliyet, 28 Teşrîn-i Evvel/Ekim 1933.

${ }^{62}$ Bilge, Güç Komşuluk, s.110.

${ }^{63}$ İsmet Pasa'nun Siyasi ve İctimai Nutukları, s.489 vd.

${ }^{64}$ Akşam, 28 Teşrîn-i Evvel/Ekim 1933; Vakit, 28 Birinci Teşrin/Ekim 1933

${ }_{65}$ Suat Bilge, Türkiye Sovyetler Birliği İlişkileri, 1920-1964 (Güç Komşuluk), Ankara, 1992, s.110. "Burada Türkiye ile Sovyet Rusya'nın harsî ve ilim sahasında mütemadiyen artan rabıtalarını da kaydetmek icap eder..." Cumhuriyet, 28 Teşrîn-i Evvel/Ekim 1933. "Biz yabancı toprakları fethetmek arzusuna sahip değiliz. Ordularımız barıș için oluşturulan unsurlardır. Daha azimli, daha mücadeleci daha kolay bir șekilde biz halklarımızın acı çekeceği ve daha fazla kayıp vereceği yeni bir savaş tehlikesini azaltmayı başarabiliriz" J.Degras, Soviet Documents on Foreign Policy, c.III, London, 1952, s.32-33. 
Voroşilov Heyeti'nin Ankara'ya gelişi ve İsmet Paşa'nın ziyafetinde yaptığı konuşmayı Falih Rıfkı Bey gazetesinde şöyle değerlendirmekteydi. "Dün akşam bizim için söyleyen Başvekil İsmet Paşa ve Moskova için söyleyen Voroşilof Yoldaş, iki tarafın muharrirlerini yeni bir şey bulup yazmakta müşkülata uğrattılar. Tekrar yalnız hakikati eskitmez. Onun için fikrimizi bir daha bildirmek ve iki memleket halk kitlelerinin birbirine yakınlığından kuvvet almaktadır: En sağlam bağ, muhakeme ve tahlil edilmeyecek kadar şuurlaşmış olan muhabbettir ${ }^{66}$.

Heyetin Ankara'daki ikinci gününde de yoğun bir programı vardı. Saat 10'dan itibaren İsmet Paşa Kız Enstitüsü'ndeki Eğitim Sergisi'ni ve Gazi Muallim Mektebi'ni, İktisat Sergisi'ni, Ziraat Enstitüsü'nü gezdi. Saat 13.45'te TBMM Reisi tarafından Halkevinde bir öğle yemeği verilmiş, 17.00'de Erkân-1 Harbiye Reisi tarafından bir çay ziyafeti, akşam 20.30'da da Ankara Sovyet Büyükelçisi tarafından büyükelçilik binasında ziyafet ve kabul resmi takip etmişti ${ }^{67}$.

Bu sırada heyetin beraberinde getirdiği hediyelerde takdim edilmişti. Bu hediyeler arasında en dikkat çekici olanı kıymetli iki cins at idi. Bunlar Sovyet hükümeti tarafından Gazi Paşa Hazretleri ve Başvekil İsmet Paşa'ya takdim edilmişti. Ayrıca heyetle birlikte gelen Rus muharriri Zarhi tarafından Türk inkılâbını tasvir ve hatırası için çevrilecek film için hazırlıklar yapılmış ve çalışmalar da başlamı̧̧t ${ }^{68}$.

29 Ekim 1933 tarihinde de misafirler cumhuriyetin onuncu yıldönümü münasebetiyle yapılacak merasim ve şenliklere iştirak etmişlerdi. Ve Voroşilov törenlerde gördükleri, özellikle, ordu hakkındaki intibaını da Anadolu Ajansı'na verdiği demeçte dile getirmişti. Bu demecinde şu dikkat çekici ifadeleri kullanıyordu: "Geçit resminde gördüğüm, ordu, ellerine Türkiye Cumhuriyeti'nin istiklalinin tevdi olunabileceği bir muhafızdır ve bu ordu aynı derecede sulhün kuvvetli bir istinatgâhıdır. Bu mükemmel geçit resmini idare edenlerle geçit resmine iştirak edenlerin hepsini selamlamak için bu fırsattan istifade ediyorum, ${ }^{, 69}$ Kutlamaların ardından gece düzenlenen baloya Voroşilov ve Mustafa Kemal Paşa birlikte gelmişti. Burada Voroşilov, Rus halk dansı yapınca buna karşılık Mustafa Kemal Paşa da zeybek oynayarak jest yapar. Gece boyunca yapılan görüşmelerde dünyanın yeni bir savaşın eşiğinde olduğu noktasında fikir teatileri yapılır. Hatta Voroşilov Mustafa Kemal'e, "Bu harbde Şark ordularının Başkumandanlık vazifesini siz görecesiniz", der. ${ }^{70}$

\footnotetext{
${ }^{66}$ Hâkimiyet-i Milliye, 28 Birinci Teşrin/Ekim 1933.

${ }^{67}$ B.C.A., 030.10/198.352.14, Varak No:3.

${ }^{68}$ Milliyet, 27 Teşrîn-i Evvel/Ekim 1933.

${ }^{69}$ Hâkimiyet-i Milliye, 31 Birinci Teşrin/Ekim 1933.

${ }^{70}$ Perinçek; Atatürk'ün Sovyetlerle Görüşmeleri, s.216. Onuncu yılda Atatürk, Ankara Palas'ta verilen balodan gece saat üçte ayrılarak Halkevinde ayrıca verilen baloya geldi. Gençlerle beraber onuncu yıl marşını söyledi. Maiyetinde Rus misafirler de bulunuyordu.

Bir aralık caz takımı Kazaskayı çaldı. Voroşilof ortaya çıkarak Kazaska oynadı. Oynayıp yerine oturunca Atatürk salonun ortasına gelerek ceza parmağıyla zeybek havası
} 
Ve geceye Sovyet Rusya İcra Komitesi Reisi Mihail İvanoviç Kalinin'in cumhuriyetin 10 . Y1l dönümü münasebetiyle Mustafa Kemal Paşa'ya çektiği kutlama telgrafı damgasını vurur. Buna cevap olarak da Mustafa Kemal Paşa duygularını şöyle ifade eder:

"Cumhuriyetin onuncu yıldönümü münasebetiyle bana keşide buyurduğunuz telgrafı büyük bir memnuniyetle aldım. Büyük dost memleketin merkezi İcra Komitesi'nin M.Voroşilov gibi mümtaz bir şahsiyetin reisliğinde bir heyet-i bayramımıza iştirak ettirmek suretiyle vaki nazik alakası bizi pek ziyade mütehassis etti. Bu büyük bayram günlerinde hissettiğimiz sevinç yanı başımızda ilk günler dostlarımızın mevcudiyetiyle bir kat daha çoğaldı..."

Heyetin dört günlük Ankara ziyareti misafirlerin Ankara-Kayseri treni güzergahında yaptıkları gezinti ile sona ermiști. Program gereğince veda zamanı gelmiști. 30 Kasım pazartesi akșamı saat 21.50'de hareket edilecekti. Özel tren Eskişehir-Kütahya-Balıkesir güzergahıyla İzmir'e hareket edecekti. Heyet ziyaretlerin ardından hoş bir seda bırakarak Ankara'dan ayrılmıştı.

Heyet, güzergah üzerindeki vilayetlerde de birtakım incelemeler yapma fırsatı bulabilmişti. Heyetle birlikte Hariciye Vekili Tevfik Rüştü ve Milli Müdafaa Vekili Zekaî Beyler Eskişehir'e uğramıştı. Kötü hava şartlarına rağmen halkın tezahüratları arasında karşılanmışlardı. Burada kaldıkları süre içinde tayyare müesseselerini ve şeker fabrikasını gezme firsatı bulmuşlardı ${ }^{72}$. Heyeti götüren özel tren $1 \mathrm{Kasım} \mathrm{Çarşamba} \mathrm{günü} \mathrm{saat} \mathrm{9'da}$ İzmir'e gelebilmişti. Misafirleri istasyonda vali ve belediye reisi başta olmak üzere diğer devlet erkânı askerî merasim ile karşılamıştı. Sonra resmî ziyaretler yapılmış ve Kız Muallim Mektebi, Belediye Çocuk Yuvası ve Sağır Dilsiz Mektebi ziyaret edilmişti. Ertesi günü de İzmir'in sanayi kuruluşları ve sivil örgütleri ziyaret edilmiş, aynı gün birtakım sportif faaliyetleri izleme fursatı bulmuşlardı ${ }^{73}$.

Voroşilov, burada onuruna verilen bir yemekte şu çarpıcı ifadeyi kullanır:" Dünyada iki ideal vardır. Biri biz, diğeri siz diyerek iki devrimin sosyalist devrimler ve ulusal savaşlar çağını açtığını vurgular,"74. Bu ziyaretin anısına da belediyenin kararıyla İzmir'de büyük bir caddeye "Voroşilof

çalmasını emretti. Caz zeybek çalmağa başlayınca Atatürk de çok mükemmel bir surette zeybek oynadı. Ecnebi misafirler ve salonu dolduranlar her tarafı alkış tufanına garkettiler. Yerine oturup şampanya kadehini kaldırarak:

-İste bizim de böyle erkekçe bir oyunumuz var! Dedi.

E.Behnan Şapolyo, Kemal Atatürk ve Milli Mücadele Tarihi, 3.bs, İstanbul, 1958, s.527-528.

${ }^{71}$ Atatürk'ün Tamim, Telgraf ve Beyannameleri, c.IV, Ankara, 1991, s.642-25;

Rasih Nuri İleri, Atatürk ve Komünizm, İstanbul, 1970, s.22.

${ }^{72}$ Hâkimiyet-i Milliye, 3 Birinci Tesrin/Ekim 1933.

${ }^{73}$ B.C.A. 030.10/198.352.14, Varak No:5.

${ }^{74}$ Perinçek, Atatürk'ün Sovyetlerle Görüşmeleri, s.219. 
Caddesi" adı verildi ${ }^{75}$. "Ayrıca şehir meclisi bu ziyaretin anısına Voroşilov'a İzmir'in fahri hemşehrisi unvanını verdiklerini ilan etmişlerdi ${ }^{76}$.

Ertesi günü heyet, harabeleri gezmek maksadıyla İzmir Vapuru ile Bergama'ya gitti. Heyet, burada da merasim ve halkın tezahüratlarıyla karşılanmıştı. Sonra tarihi harabeler gezilmiş halkevinde onuruna öğle yemeği verilmiş ve İzzmir'e dönülmüştü ${ }^{77}$.

İzmir'de ziyaretlerini tamamlayan heyet, buradan İstanbul'a gitmek üzere İzmir Vapuru ile 2 Kasım Perşembe saat 21.00 'da hareket etmişti. İzmir Vapuru'nu Çanakkale Boğazı'nda iki torpido karşılamıștı. Heyet İzmir'den İstanbul'a gelirken Çanakkale'yi de gezmek istemişti. Özellikle Birinci Dünya Savaşı yıllarından kalan muharebe yerlerini gezmek istemişlerdi. Heyetle birlikte Hariciye Vekili Tevfik Rüştü Bey ve III. Ordu Müfettişi İzzettin Paşa (Çalışlar) da bulunmaktayd ${ }^{78}$.

Heyeti getiren İzmir Vapuru 3 Kasım Cuma günü akşam saat 17.00'da İstanbul'a ulaşabildi. Heyet, İstanbul Valisi, Kolordu Kumandanı ve diğer devlet erkânı tarafından karşılanmış, akşam 20.30'da da Pera Palace Oteli'nde Kolordu Kumandanı tarafından bir ziyafet verilmişti ${ }^{79}$.

Misafirler İstanbul'dan ayrılacakları $7 \mathrm{Kasım} \mathrm{Salı} \mathrm{gününe} \mathrm{kadar}$ oldukça yoğun bir program takip etmişlerdi. Bu süre içinde Topkapı Sarayı'nı, Asar-1 Atika Müzesini ve Evkaf Müzesi'ni Dolmabahçe Sarayı'nı, İstanbul Kız Muallim Mektebi'ni, Beykoz Dericilik Fabrikası'nı gezmişler, birçok yemeğe ve kabul resmine, Darülbedayi tiyatrosunda bulunmuşlardı ${ }^{80}$.

Rus Heyeti'nin Türkiye'de bulunduğu sıralarda Sovyet Rusya'da Ekim Devrimi'nin 16. yıldönümü kutlanmaktaydı. Bu maksatla Mustafa Kemal Paşa, Kalinin'e bir kutlama telgrafı çeker, buna Kalinin'in cevabı yine dostça olur ve şunları ifade eder: "Ekim Devrimi'nin 16. yıldönümü dolayısıyla kutlamanız derinden etkiledi. Sovyetler birliği halkı, iktisadi ve kültürel yapılanma alanındaki yeterliliğinin ve dünya politikasındaki başarılarının bilançosunu yaparken sizin önderliğinizde büyük başarılar elde eden ve bu günlerde şanlı 10. y1ldönümünü kutlayan Türkiye Cumhuriyeti halkının sarsılmaz dostluğunun önemle altını çiziyor" ${ }^{\prime \prime}$.

${ }^{75}$ İsmet İnönü, Hatıralar, C.II, Ankara, 1987, s.254. Heyet İzmir'de Bornova'daki Ziraat Mektebi'ne de gitmişti: Voroşilof ve Sovyet Heyeti Mektebi hakikaten güzel bulmuşlar ve General Voroşilof 1925 senesinde yazılmıs Gazi'nin kıymetli bir yazı ve imzasını tașıan mektebin defterine şu yazıları yazmıştır. "Bize idarecileri tarafından büyük bir aşk ve muhabbetle gösterilen Ziraat Mektebi hakikaten mükemmel bir teşkilata sahiptir: Ve herhangi bir memleketin herhangi bir sehri için iftihar edilecek bir mekteptir. Talebelerine ve muallimlerine saadet ve muvaffakiyet dilerim..." Hâkimiyet-i Milliye, 5 İkinci Teşrin/ Kasım 1933.

${ }^{76}$ Hâkimiyet-i Milliye, 10 İkinci Teşrin/ Kasım 1933.

${ }^{77}$ Hâkimiyet-i Milliye, 6 İkinci Teşrin/ Kasım 1933.

${ }^{78}$ Hâkimiyet-i Milliye, 7 İkinci Teşrin/ Kasım 1933.

${ }^{79}$ B.C.A., 030.10/198.352.14, Varak No:5.

${ }^{80}$ B.C.A., 030.10/198.352.14, Varak No:5,6.

${ }^{81}$ Perinçek, Atatürk'ün Sovyetlerle Görüşmeleri, s.219. 
Sovyet Heyeti'nin 13 günlük Türkiye ziyareti artık tamamlanmıştı. Heyet Başkanı Voroşilov, bu ziyaret hakkında edindiği izlenimleri değerlendirmek maksadıyla Türk ve yabancı gazetecilerle bir basın toplantısı düzenledi. Bu toplantıda; Türkiye'ye geldiği andan itibaren ve gittiği her yerde Türk halkının misafirperverliğini, samimi alkışlarını ülkede kültürel ve iktisadi anlamda yapılan yatırımları, Ankara'yı, gezdiği sergileri, okulları, Türk ordusunu ve görme fırsatı yakaladığı diğer şehirleri tek tek değerlendirdi. Bu seyahatten beklentilerini de şöyle izah etmekteydi: "Ben o kanaatteyim ki, yaptığımız bu seyahatin bu derece kuvvetlendiğini dostça ve samimi temas, sulh uğurunda giriștiğimiz, insanlık aleminin her türlü elemleri, 1stırapları, tahrip ve imhalarıyla tehdit eden harbin önüne geçmek için yaptığımız müşterek mücadeleyi bundan sonra daha büyük bir azim ve kuvvetle yürütüp ilerletmemizi mümkün kılacaktır...

Misafirperver memleketinizden bugün ayrılmak üzere bulunduğum şu dakikalarda bize karşı gösterdikleri kabul tarzından dolayı Türk milletine ve Türkiye Cumhuriyeti hükümetine teşekkürlerimizi, saadet ve refah dileklerimizi bir defa daha matbuat vasıtasıyla iblağ fırsatından istifade ediyorum.." ${ }^{22}$

7 Kasım 1933 Salı günü de heyet vapurla Adalar ve Yalova'ya bir gezinti yaptı. Böylece heyet resmi programını tamamlamış oldu. Akşam 20.00 'da da geldikleri İzmir Vapuru ile Rusya'ya dönecekti. Ve misafirler yine halkın büyük coşkusu ve resmi makamların eşliğinde İzmir Vapuru ile ülkelerine uğurlanmıștı. Heyete III. Ordu Müfettişi İzzettin Paşa da Odessa'ya kadar eşlik etmesi için görevlendirilmişti ${ }^{83}$. Böylece heyetin Türkiye'ye geliş maksadının gerçekleşmiş olması, dünya basınında ve diplomatik çevrelerde büyük yank1 uyandırması buna bir ölçü olmuştu ${ }^{84}$.

Voroşilov Heyeti'nin Türkiye ziyareti böylece tamamlanmış oldu. Heyetin Moskova'ya gidişinden sonra edinilen intibaların resmi makamlarca paylaşılması sonucu Türkiye'nin misafirperverliği ve dostluğuna, heyete olan ilgisine karşılık olarak Sovyet Rusya Merkezi İcra Komitesi Reisi Kalinin, Türkiye Reis-i Cumhuru Gazi Mustafa Kemal Paşa'ya bir telgraf göndererek memnuniyetini ifade etmişti. Bu mesajında Kalinin şunları ifade etmişti: “Sovyet Heyeti'nin Türkiye'deki ikametlerinden getirmiş olduğu unutulmaz intiba memleketlerimiz milletlerinin kendilerini mütekabil ve tam bir anlaşmayan sıkı bir teşrik-i mesaiye ve bozulmaz bir dostluğa isal etmiş olan tarihi inkişaf yolunun ne kadar doğru olduğunu göstermişti. Sovyet Heyeti'nin Türkiye'yi ziyaretinin ve orada görmüş olduğu dostane kabulün ve dostluğun ileride daha ziyade kuvvet bulmasına ve memleketlerimizin

\footnotetext{
${ }^{82}$ Hâkimiyet-i Milliye, 10 İkinci Teșrin/ Kasım 1933.

${ }^{83}$ İzzettin Paşa, burada büyük sevgi gösterileri arasında ağırlanmış, onuruna yemekler verilmiști. Hâkimiyet-i Milliye, 12 İkinci Teşrin/ Kasım 1933.

${ }_{84}$ Perinçek, Atatürk'ün Sovyetlerle Görüssmeleri, s.220. Türk gazetelerde heyetin kanaatlerini şu ifadelerle dile getiriyordu. "Memleketimize Türk-Sovyet dostluğunun metaneti hakkında kati bir kanaatle dönüyoruz" Hâkimiyet-i Milliye, 11 İkinci Teşrin/ Kasım 1933.
} 
daha feyyaz bir surette teşrik-i mesai etmelerine medar olacağına derin bir surette kaniim..."

Buna karşılık olarak da Gazi Mustafa Kemal Paşa da bir telgrafla ziyaretten duyduğu memnuniyeti ifade etmiş ve ziyaretin iki ülke arasındaki dostluğu pekiştirdiğinin vurgusunu yapmışt ${ }^{85}$.

\section{SONUÇ}

1920'lerden 1930'lara Türk dış politikası; hedef ve amaçlarındaki tutarlılık, gerçeklik, karşılaşılan problemlerdeki soğukkanlılık ve taktik ustalığı, diyaloğa açık olmak gibi ilkelere dayandırılmaya çalışılmıştı. Bunlardan hareketle de mevcut problemlere çözümler aranmış, gerektiğinde de ittifaklar kurmaya çalışılmış, ayrıca Mustafa Kemal Paşa'nın "Yurtta barış dünyada barış" hedeflerine uygun olarak da stratejiler takip edilmişti ${ }^{86}$

$\mathrm{Bu}$ ilkeler çerçevesinde Türkiye Cumhuriyeti kuruluşundan itibaren Sovyet Rusya ile dostluğa önem vermiş; Karşılıklı ziyaretlerle bu dostluk pekiştirilmeye çalışılmıştı. Bunların sonuncudur ki Türkiye, Lozan sonrası yalnız kalmamıştı. Ancak 1930'lardan itibaren Türkiye'nin yönünü batıya çevirme çabaları, Türkiye'nin 1932'de Milletler Cemiyeti'ne girmesi, 1934 yılında da Türkiye'nin Balkan Paktı'nın kurulması için ortaya koyduğu performası Rusya'nın Türkiye'ye karşı endişelerini artırmıştı. Bu aşamalar Sovyet Rusya açısından sorun idi. İşte bu gibi sorunlar karşısında her iki ülkenin sorunları çözmek adına karşılıklı heyetler göndermeleri dikkat çekiciydi. Kliment Yefromoviç Voroşilov'un Türkiye'yi ziyareti de iki ülke adına sevindirici gelişmelere büyük katkı sağlamaya hizmet etmişti. Bu ziyaretin ilk somut adımları da iktisadî ve kültürel alanlarda kendini göstermişti. Mesela bu yakınlığın sonucunda Kayseri'de bir bez fabrikasının kurulması gerçekleştirilebilmişti ${ }^{87}$.

Sonuç olarak şu söylenebilir: İki dünya savaşı arasında tesis edilmeye çalışılan bu dostluk Kliment Yefromoviç Voroşilov Heyeti'nin Türkiye'yi ziyaretiyle daha da bir anlam kazanmış oldu. Ancak yaklaşan savaş, dünyanın kutuplaşması ve Türkiye'nin mecburen yönünü batıya çevirmesi bu dostluğun bir müddet sonra ortadan kalkmasını hazırlayan nedenler olacaktır.

${ }^{85}$ Atatürk'ün Milli Dış Politikası 1923-1938 (Cumhuriyet Dönemine Aid 100 Belge), , c.II, Ankara, 1981, s.231-32. vd.

${ }_{86}$ Atatürk Dönemi Türk Dış Politikası, (Haz.) Berna Türkdoğan, Ankara, 2000, s.13-

${ }^{87}$ Burçak, Moskova Görüşmeleri, s.15-16. 